\title{
Managing for Multiple Resources Under Climate Change: National Forests
}

\author{
Linda A. Joyce $\cdot$ Geoffrey M. Blate • \\ Steven G. McNulty · Constance I. Millar • \\ Susanne Moser · Ronald P. Neilson • \\ David L. Peterson
}

Received: 30 September 2008/Accepted: 26 May 2009/Published online: 9 July 2009

(C) U.S. Government 2009

\begin{abstract}
This study explores potential adaptation approaches in planning and management that the United States Forest Service might adopt to help achieve its goals and objectives in the face of climate change. Availability of information, vulnerability of ecological and socio-economic systems, and uncertainties associated with climate change, as well as the interacting non-climatic changes, influence selection of the adaptation approach. Resource assessments are opportunities to develop strategic information that could be used to identify and link adaptation strategies across planning levels. Within a National Forest, planning must incorporate the opportunity to identify vulnerabilities to climate change as well as incorporate approaches that allow management adjustments as the
\end{abstract}

After Linda Joyce, the authors are listed alphabetically.

L. A. Joyce $(\square)$

USFS Rocky Mountain Research Station, 240 West Prospect, Fort Collins, CO 80526, USA

e-mail: ljoyce@fs.fed.us

G. M. Blate

Policy Office, WWF Greater Mekong Programme, Chulawich 1

Building, Chulalongkorn University, Henri Dunant Road,

Bankgok 10330, Thailand

S. G. McNulty

Southern Global Change Program, USFS Southern Research

Station, 920 Main Campus Drive, Venture Center II, Suite 300,

Raleigh, NC 27606, USA

\section{I. Millar}

Sierra Nevada Research Center, USFS Pacific Southwest

Research Station, 800 Buchanan Street, Albany, CA 94710, USA

\section{S. Moser}

Institute of Marine Sciences, University of California-Santa

Cruz, Santa Cruz, CA 95060, USA effects of climate change become apparent. The nature of environmental variability, the inevitability of novelty and surprise, and the range of management objectives and situations across the National Forest System implies that no single approach will fit all situations. A toolbox of management options would include practices focused on forestalling climate change effects by building resistance and resilience into current ecosystems, and on managing for change by enabling plants, animals, and ecosystems to adapt to climate change. Better and more widespread implementation of already known practices that reduce the impact of existing stressors represents an important "no regrets" strategy. These management opportunities will require agency consideration of its adaptive

S. Moser

Susanne Moser Research \& Consulting, 134 Shelter Lagoon Drive, Santa Cruz, CA 95060, USA

R. P. Neilson

USFS Pacific Northwest Research Station, 3200 S.W. Jefferson Way, Corvallis, OR 97331, USA

D. L. Peterson

USFS Pacific Wildland Fire Sciences Laboratory, 400 N 34th

Street, Suite 201, Seattle, WA 98103, USA 
capacity, and ways to overcome potential barriers to these adaptation options.

Keywords Resilience $\cdot$ Resistance $\cdot$ Anticipatory management $\cdot$ Planning $\cdot$ Assessments $\cdot$ Adaptation

\section{Introduction}

Climate change will directly affect ecosystems through seasonal increases in air temperature and changes in precipitation, and indirectly through the effect of climate change on disturbances such as fire and drought (IPCC 2007a; CCSP 2008). Ryan and others (2008) noted that climate change already has very likely altered forest fires, insect outbreaks and tree mortality in the U.S. interior west and southwest; areas with significant holdings of federally managed lands. On arid lands, increased erosion and nonnative species invasion will be enhanced by climate change effects such as higher temperatures and increased drought (CCSP 2008). The National Forest System (NFS), a U.S. federally managed system of 155 national forests (NF) and 20 national grasslands (NG), harbors much of the terrestrial biodiversity in the United States, provides important habitat for many rare, threatened, and endangered plants and animals, and supplies many urban areas with drinking water from the high-elevation watersheds. National forests and national grasslands will experience increased exposure to many current climate risks, encounter new risks and new opportunities with significant implications to ecosystem services such as clean water produced from NFs, infrastructure such as roads, and economies of the nearby communities (IPCC 2007a; CCSP 2008).

Unlike federal lands that are afforded strict protection (Baron and others 2008), the US Forest Service (FS), as the steward of the NFS, actively manages the multiple natural resources on the NFs and NGs to achieve national goals (Table 1) as well as goals identified for each NF and NG. Yet,

Table 1 Strategic plan goals of the US Forest Service, 2007-2012 (US Forest Service 2007)

\begin{tabular}{ll}
\hline Number & Goal \\
\hline 1 & $\begin{array}{c}\text { Restore, sustain, and enhance the nation's forests } \\
\text { and grasslands. }\end{array}$ \\
2 & $\begin{array}{l}\text { Provide and sustain benefits to the American people. } \\
3\end{array}$ \\
4 & Conserve open space. \\
5 & $\begin{array}{l}\text { Maintain basic management capabilities of the Forest } \\
\text { service. }\end{array}$ \\
6 & $\begin{array}{l}\text { Engage urban America with Forest Service programs } \\
7\end{array}$ \\
& Provide science-based applications and tools for sustainable \\
& natural resources management
\end{tabular}

in 2007, the Government Accounting Office documented that federal resource managers lack specific guidance for incorporating climate change into their management actions and planning efforts (GAO 2007). Further, the GAO recommended that the Secretaries of Agriculture, Commerce, and the Interior develop guidance for federal managers on how to address climate change effects on the resources they manage.

This study explores options that the FS might adopt to help achieve its goals and objectives in the face of climate change. We describe adaptation in the context of natural resource management. We identify opportunities for the agency to use in the current planning processes and to facilitate on-the-ground management. We bring these adaptation options back to the challenge of managing for multiple resources, the agency's mission. And although we focus on the NFS, this study is relevant to land and resource managers on privately owned or publicly managed lands in the United States or internationally who must balance and actively manage for a suite of objectives and goals, in consideration of external influences on their lands.

\section{Adaptation to Climate Change: Plants, Animals, and Humans}

In nature, adaptation occurs autonomously (i.e., reactively) as species and ecosystems respond to environmental change such as climate forcing (Davis and Shaw 2001; Schneider and Root 2002). Natural adaptation by plants and animals can occur through genetic changes, in situ acclimation (i.e., physiological adaptation to the changing environment while remaining in place) and changes in phenology and behavior. Human adaptation occurs both autonomously and in a planned, anticipatory fashion as people make adjustments in response to climate stimuli and their effects so as to moderate the impact or to capitalize on an opportunity (Smit and Wandel 2006; Adger and others 2007; Lemmen and others 2008). These adjustments in the Forest Service will be made in light of the institution's goals and objectives (Table 1).

The feasibility and effectiveness of adaptation strategies will depend on the characteristics and interactions of local systems-ecological, economic, and social (Adger 2003; Smit and Wandel 2006). Adaptive capacity is the ability to adjust to climate change, to moderate potential damages, to take advantage of opportunities, or to cope with the consequences (IPCC 2007b). For ecosystems, the ability to adapt to climate variability and change is influenced by local characteristics such as topography and micro-refugia, existing biodiversity, presence of invasive species, the successional ecosystem state, and fragmentation of the landscape (Blaikie and others 1994; Wilbanks and Kates 1999; Adger 2003). For resource managers and the NF or NG, the ability to adapt is influenced by experience and training, 
available staffing, available financial resources, reward system, institutional flexibility and public support. In addition, non-local factors influence local adaptive capacity through the larger socioeconomic and political systems. Examples include federal laws, federal forest policies and regulations, state air quality standards, development pressures along the forest/urban interface, and commodity market conditions.

Effectiveness and cost-efficiencies in adaptation may also be influenced by the timing of management or planning. For example, a management response might be planned before but implemented only during or after a major climatic event or unprecedented large disturbance such as flooding or wildfire. These events could be viewed as "windows of opportunity" for implementing adaptation practices, such as adjusting the size of management units, addressing infrastructure needs, or revisiting objectives. While significant cost efficiencies might be achieved, such an approach might be difficult to implement, as crises often engender political and social conditions that favor "returning to the status quo" that existed prior to the crisis rather than doing something new (for example, Moser 2005).

Under the continually changing climate, there will be a recurrent need to adjust management, and perhaps goals. It might not be possible to manage all climate change effects. The decision not to manage for a particular species or ecosystem service might reflect a project or management so costly to undertake, fraught with failure that it renders other projects impossible to undertake by virtue of absorbing all available resources. The focus might shift from maintaining existing ecosystem services to management that supports natural adaptive processes such as facilitating species migration or to management that focuses on future options such as long-term seed bank storage for re-establishing populations in new and more appropriate locations.

Resource managers will need to discern when current species or ecosystem services cannot be maintained. Importantly, such an approach would need to involve managers at various levels to monitor ecological change; coordinate and make appropriate changes in policies, regulations, plans, programs and the budget process at all relevant scales; and modify the on-the-ground practices. This degree of cross-scale integration is not typically achieved at present, and would need to occur in the future to effectively support such an adaptation approach. This adjustment will also require the public's acceptance of changes in ecosystem services coming from NFS lands.

\section{Approaches for Planning in the Context of Climate Change}

Planning processes in the Forest Service are guided by the Renewable Resources Planning Act (RPA) of 1974 and the
National Forest Management Act of 1976. The RPA calls for a periodic national assessment of the renewable resources of the U.S. to provide reliable information to properly manage natural resources and make informed policy decisions. The need for information has broadened from a solely economic concern with supply and demand to concern about resource conditions, ecosystem health, and sustainability (USDA Forest Service 2000).

The only legislatively required analysis of climate change in FS planning was specified in the 1990 amendment to the RPA. The national assessment was expanded to include the analysis of: (1) the effects of climate change on renewable resources in U.S. forests and rangelands, and (2) rural and urban forestry opportunities to mitigate the buildup of atmospheric carbon dioxide (Joyce and Birdsey 2000). Since 1990, RPA Assessments have included an analysis of the effects of climate change on ecosystem productivity, timber supply and demand, and carbon storage (USDA Forest Service 1994, 2000).

At the level of each NF, planning is guided by regulations (known as rules) developed by the Secretary of Agriculture. The 2008 rule describes the NFS land management planning framework, sets up requirements for sustainability of social, economic, and ecological systems; and gives directions for developing, amending, revising, and monitoring these plans (http://www.fs.fed.us/emc/nfma/includes/planning_rule/08_ planning_rule.pdf). No specific direction on climate change was included in the 2008 rule.

\section{Integrate Natural Resource Assessments Across} Agency Planning Levels

The integration of climate change and climate change effects on ecosystem services into policy development and planning across all levels of the agency-FS strategic goals, RPA Assessment, NF plans, multi-forest plans, project planning - could facilitate a cohesive identification of institutional, ecological and social opportunities and barriers to adaptation. Given the large spatial scale of climate projections, quantitative approaches at the national/ regional scales might provide strategic guidance for broad consideration of climate change opportunities and impacts to management activities at finer scales (for example, Iverson and Prasad 2001; Felzer and others 2004; McKenzie and others 2004; Scholze and others 2006; Bachelet and others 2008). Further broader social and economic factors could be considered quantitatively at the national level as well as the interactions and influences across regions in terms of supplying ecosystem services (for example, Irland and others 2001; Joyce 2007). The RPA assessment process could be expanded to encompass other resources currently addressed without climate change, such as water, recreation, and wildlife (USDA Forest Service 2000). Such an 
approach could involve a broad spectrum of scenarios including climatic, economic, and policy-related questions specific to the Forest Service mission.

The integration of these analyses across agency levels could facilitate identification of approaches to uncertainty and risk, appropriate spatial and temporal scales for modeling linked to decision making, and the sharing of needed expertise and resources for planning across the agency. National assessments could include consideration of how vulnerabilities might be identified, given the available information, and identify situations where the climate change effects might be locally buffered in NFs. Such a linked assessment could guide NFs and their partners in developing a process to assess the effects of climate change on natural resources and ecosystem services within their boundaries, across their boundaries, and at larger spatial scales. To identify and provide the most relevant information to support an anticipatory approach to adaptation, it is critical that scientists, managers, and stakeholders work together to form a growing mutual understanding of information needs and research capabilities in the context of ongoing, trusted relationships (Cash and Borck 2006; Vogel and others 2007; Littell and others in review).

Identify Vulnerabilities to Climate Change as Part of Forest and Project Planning

At the NF level, the planning process includes an identification of the desired future conditions, objectives, guidelines for management, suitability of areas, and special areas. Desired future conditions encompass the social, economic, and ecological attributes toward which management of the land and resources are to be directed. Desired conditions are aspirations, not final decisions approving projects and activities, and may be achievable only over a long time period.

Spittlehouse and Stewart (2003) identify several specific planning steps as appropriate in a climate-change context. Their first step of define the issue (management situation, goals, and environmental and institutional contexts) is similar to components of the current FS planning process. They then add additional steps that: (2) evaluate vulnerabilities under changing conditions, (3) identify suitable adaptive actions that can be taken at present or in the short term, and (4) develop suitable adaptive actions that could be taken in the longer term. Determining the vulnerability of NFs and NGs to climate change could involve a process as described by Johnston and Williamson (2007) where exposure, system sensitivity and adaptive capacity are assessed. Alternatively, the underlying assumptions and vulnerabilities to climate change might be identified through a science-based assessment of existing forest or project planning documents. The purpose would be to determine the level of adaptive capacity, flexibility, pitfalls, and areas for improvement in current plans and operations.

The public has the opportunity to comment on proposed actions and alternatives that could have a significant environmental effect as required by the National Environmental Policy Act (NEPA) of 1970 or through participation in the NF planning process as required by the National Forest Management Act of 1976. In addition to the scoping process in plan development, involvement of the public could take several different forms, such as Science Days where experts present the latest information on climate change and natural resource management to staff and stakeholders for an individual NF or "town-hall" meetings where a variety of stakeholders and staff from multiple NFs explore current understanding and discuss potential future effects of climate change (http://www.srs.fs.usda.gov/futures/).

Over time, managers will need to anticipate and plan for surprise and threshold effects associated with climate change that are difficult to predict with certainty yet certain to result from the interaction of climate change and other stressors. An adaptive management approach developed in the forest plan could be used to test assumptions about ecological change and make adjustments in the plan goals and objectives as the local effects of climate change become apparent (West 2005, Table 2). These assumptions would allow the plan components to be designed in a way that allows for adaptation to climate change, even though the magnitude and direction of that change is uncertain at the time of plan development.

\section{Approaches for Management in the Context of Climate Change}

Management actions on the over 76 million hectares in the NFS are reviewed or made in conjunction with other federal and state agencies, open to public comment, and implemented in a landscape mosaic of federal, state, and private land holdings. Federal agencies, such as the Environmental Protection Agency, the Fish and Wildlife Service, the National Marine Fisheries Service, and the Bureau of Land Management, have statutory review responsibilities for some management actions within the NFS. Collaborative management across multiple agencies is required on nearly a quarter of NFS land that has been statutorily set aside in national networks for wildernesses, monuments, recreation areas, game refuges and wildlife preserves, wild and scenic rivers, scenic areas, and primitive areas. Checkerboard ownership patterns within and the scattered private in-holdings of many western NFs, and the scattered land parcels of the eastern NFs result in the need to coordinate with neighboring federal and state agencies and private land owners. How the public and other federal 
Table 2 Assumptions regarding concepts used in National Forest planning to consider within plan development regarding climate change [adapted from West (2005)]

\begin{tabular}{|c|c|}
\hline Concept & Basis Considerations \\
\hline \multirow[t]{2}{*}{ Historic conditions } & $\begin{array}{l}\text { Historic conditions are a useful reference or point of comparison for current or future trends. However, this assumption } \\
\text { is likely to face substantial challenges as the effect of climate change on vegetation and disturbance regimes play out } \\
\text { over the next several decades }\end{array}$ \\
\hline & $\begin{array}{l}\text { Accordingly, an adaptive management approach can be used to test this assumption and make adjustments in } \\
\text { the desired future condition and plan goals and objectives as the local effects of climate change become } \\
\text { apparent }\end{array}$ \\
\hline
\end{tabular}

Flexibility

Although climate and ecosystem forecast models have significantly improved, they cannot produce highly accurate local projections. Flexibility to address the inherent uncertainty about local effects of climate change could be achieved through enhancing the resiliency of forests by considering the following:

Diverse plantings will likely be more adaptable to changing conditions than will single species stands

Prescribed fire and thinning could be used to keep tree densities low to improve resistance in drought and pest infestations

Encourage local industries that can adapt to or cope with variable kinds of forest products because of the uncertainty in which tree species will prosper

Reforestation after wildfire may require different species than were present on the site pre-fire to better match site-type changes associated with climate effects

Behavior of invasive species is likely to be different as climates shift

Adaptive management Effects of climate change may become more apparent with new information, and this information may be useful for adjusting desired conditions and guidelines as plans are implemented

Information of interest includes the frequency, severity, and area trends of wildfire and insect/disease disturbances, stratified by environment; the changing distribution of major forest types; stream flow and other indicators of the forests' ability to produce water of particular quality and quantity

agencies perceive climate change and react to FS management proposals will also influence how successfully the FS can implement adaptation.

A primary premise for managing under climate change is that change, novelty, uncertainty, and uniqueness of individual situations are expected to increasingly define the planning backdrop of the future. Rapid changes that are expected in physical conditions and ecological responses suggest that management goals and approaches will be most successful when they emphasize ecological processes such as nutrient cycling and soil protection, rather than focusing primarily on a particular structure and composition of plant species (Millar and others 2007). Information needs (for example, anticipated ecological responses) will vary in availability and accuracy at local spatial scales. Thus, strategic flexibility and willingness to work in a context of varying uncertainty will improve success at every level (Anderson and others 2003).

\section{Develop a Toolbox of Management Options}

No single adaptation approach will fit all NFs and NGs, given the nature of climate and environmental variability, the inevitability of novelty and surprise, and the range of management objectives (Spittlehouse and Stewart 2003; Hobbs and others 2006; Millar and others 2007). Given the NFS mission of multiple resources and multiple objectives, it will be necessary to integrate management practices that reflect different individual goals. From a toolbox of options, appropriate elements (and modifications) could be selected and combined to fit the environmental context as well as the multiple objectives. Existing management practices may continue to be elements but used in new locations and seasons, such as prescribed fire but outside of traditional time periods. Elements will likely also include experimenting with new management practices, such as diversifying genetic guidelines for planting.

The following framework classifies adaptation strategies in an attempt to begin to build the toolbox. Each category represents different situations and opportunities. Management addressing current stresses emphasizes relevant nearterm objectives and attempts to mitigate the potential future exacerbation of climate change on these current stressors. The next category includes management that attempts to delay the negative effects of climate change for high-valued or rare resources. And the last category includes proactive management which would enable ecosystems to adapt gradually and may reduce the potential for ecosystems crossing thresholds or significant loss of ecosystem services.

\section{Reduce Existing Stresses}

An increased emphasis on current efforts to reduce the impact of existing stressors on NFs represents a "no regrets" strategy. It is likely that the direct effects of climate change on ecosystems and the interactions of climate 
change with other major stressors might render NFs increasingly prone to more frequent, extensive, and severe disturbances, such as drought (Seager and others 2007), insect and disease outbreaks (Breshears and others 2005; Carroll and others 2004), invasive species, and wildfire (McKenzie and others 2004; Lenihan and others 2008). Efforts to mitigate existing stressors would address current management needs, and potentially reduce future interactions of these stressors with climate change.

Preparedness is an important element in reducing the potential impacts of extreme events on individuals, communities, and the environment (for example, community wildfire protection plans, individual state drought plans). Development or refinement of plans that incorporate preparedness, mitigation, and response efforts would address current stresses as well as begin to address potential adaptations to likely future events associated with the current stressors and climate change. Increased coordination among local, state, and federal government agencies as well as increased collaboration among scientists and managers would help develop public understanding of the need for preparedness and enhance the effectiveness of prediction, information delivery, and applied research.

Enhancing the effectiveness of observation networks and current monitoring efforts would provide information for the early detection of an ecological change associated with climate change (CCSP 2008). One of the four programs in the FS Invasive Species Strategy is the early detection and rapid response (EDRR) program (USDA 2004). Among the many program activities is the annual cooperative survey of federal, tribal, and private forestland for damage caused by forest insects and pathogens, and the monitoring for invasive insects in identified ports and surrounding urban forests. The EDRR focuses on solving small problems before they become large, unsolvable problems, and recognizes that proactive management is more effective than long delays in implementation. Such an approach might also be appropriate for impacts associated with climate change, by allowing managers to respond quickly to those impacts, with an eye toward adaptation (Littell and others in review).

\section{Forestall Change: Creating Resistance and Promoting Resilience to Climate Change}

Seeking to maintain the existing suite of ecosystem services for a limited period of time might be the only or best option in some cases (Millar and others 2007). This approach to adaptation options focuses on actively reducing the effects of climate change (Suffling and Scott 2002; Millar and others 2007) as well as intensifying management to return a site to a prior condition of that ecosystem in the face of climate change (for example, Spittlehouse and Stewart 2003; Millar and others 2007).

Creating resistance includes reducing stresses associated with climatic events such as drought, but also creating resistance against climate-mediated disturbance such as fire (Table 3). For ecosystems with low sensitivity to climate, maintaining ecosystem health and biodiversity is an approach that can build on our current understanding and management practices (Lemmen and Warren 2004). Highly

Table 3 Forestalling climate change includes two short-term options for building management strategies in the face of climate change: resistance and resilience; these strategies focus on maintaining the status quo in terms of ecosystems and resources

\begin{tabular}{|c|c|c|}
\hline Type & Objective & Examples of management practices \\
\hline Resistance & $\begin{array}{l}\text { Reduce effects from climatic } \\
\text { events such as drought } \\
\text { Create resistance against climate } \\
\text { mediated disturbances }\end{array}$ & $\begin{array}{l}\text { For animal species, improve their ability to migrate by creating large } \\
\text { management units and broad corridors } \\
\text { For animal species, enhance coordination among multiple agencies that manage } \\
\text { adjacent lands to ensure continuity of habitat } \\
\text { For ecosystems, improve their ability to with stand uncharacteristically severe } \\
\text { drought, insect outbreaks and wildfire by thinning and fuel abatement } \\
\text { treatments at landscape scales, maintain existing fuel breaks, develop } \\
\text { strategically placed area treatments to reduce fuel continuity, and implement } \\
\text { defensible fuel profile zones about high-value areas }\end{array}$ \\
\hline Resilience & $\begin{array}{l}\text { Combine resistance with deliberate } \\
\text { and immediate plans to } \\
\text { encourage return of the site, } \\
\text { post-disturbance, to species } \\
\text { reflective of its prior condition }\end{array}$ & $\begin{array}{l}\text { To return the site to pre-disturbance conditions, intensive site preparation to } \\
\text { remove competing vegetation; replant with high-quality genetically } \\
\text { appropriate and diverse stock } \\
\text { To enable retention of the site by desired species (for whom the site may no } \\
\text { longer be optimal), intensive management may need to be dedicated to the } \\
\text { revegetation period and through the early years of establishment } \\
\text { To promote resilience with living stands, widely spaced thinning or shelterwood } \\
\text { cuttings and rapid treatment of forest mortality by fire or insects. } \\
\text { Diligent stand-improvement practices } \\
\text { Minimize invasion of non-native species }\end{array}$ \\
\hline
\end{tabular}


sensitive ecosystems will require the most intensive management interventions to maintain current species and ecological functions (Millar and others 2007).

While promoting resilience is the most commonly suggested adaptation option discussed in a climate-change context (for example, Dale and others 2001; Spittlehouse and Stewart 2003; Harris and others 2006); definition and interpretation of resilience vary. Where resilience is defined strictly as the return to pre-disturbance conditions, management options would combine resistance practices with deliberate and immediate plans to encourage return of the site to species occurring on the site prior to the climatic event (i.e., resilience, Table 3). An example might be planting trees after a disturbance on sites that may not sustain forest cover under the changing climate.

Options to forestall undesired ecological change might best be exercised in the short-term. Critical understanding of changing environmental, social, and economic effects will be needed to evaluate success of on-going resistance and resilience practices. For example, whereas taking aggressive action against invasive species is an important step to increasing resistance, monitoring data on species range distributions might indicate that native species, considered nonnative to a particular area, are migrating. A cumulative adjustment to a changing climate might be occurring, creating the need to evaluate the original objectives. Further, over time, as environmental conditions continue to change, it may be that only so much can be done to increase ecosystem resistance and resilience, and additional efforts fail.

\section{Manage for Ecosystem Change: Enable Ecosystems to Adapt to Climate Change}

The goal of this suite of management options is to enable ecosystems to naturally adapt as environmental changes accrue (Table 4). Many species and ecological conditions will be moving naturally toward significant change in an attempt to adapt (for example, species migration, stand mortality and colonization events). These options seek to work with those natural processes, with the intention of avoiding crossing thresholds or extreme loss that might occur if natural change is cumulatively resisted or allowed to progress unmodified through disturbance events (Millar and others 2007; CCSP 2009).

Options to enable ecosystems to respond to change include assisting species transitions, increasing redundancy and diversity of habitats and managed stands as well as expanding the genetic guidelines within plantations, and developing 'neo-native' plantations and habitats (Table 4). Relevant information about future climate and ecological responses might be combined with local insight about environmental conditions to plan for species transitions to new habitats and environments (Ledig and Kitzmiller 1992; Spittlehouse and
Stewart 2003). Managers might begin to assist the transition (Halpin 1997; McLachlan and others 2007) by facilitating species migration or capitalizing on windows of opportunities to reset ecosystem trajectories. Detecting changes in native species composition and distribution through forest monitoring activities could give insight on the emerging natural adaptive responses and suggest management strategies that mimic these responses, such as new species mixes, or new locations to manage species habitats.

Increasing redundancy and buffers is an intentional approach to manage for an uncertain but changing future by spreading risks in diverse opportunities rather than concentrating them in a few (Table 4). Redundancy can be seen as planting or managing species/habitat in a variety of locales. Further, areas that supported species in the past under similar climatic conditions to those projected for the future might be considered sites for new plantation or restoration sites, "neo-native" stands of the species (Millar and others 2007). For example, Monterey pine (Pinus radiata) has naturalized along the north coast of California, well outside of and far disjunct from its present native distribution. Specific modifications of the existing guidelines for genetic management of forest plantations and restoration projects (Ledig and Kitzmiller 1992; Millar and Brubaker 2006; Ying and Yanchuk 2006) could be based on the degree of certainty known about likely future climate changes and likely environmental changes (Table 4).

Broad landscapes might be managed so that the changes in stand structure and age classes are not synchronous in time and space (Table 4). Synchronous inter-annual to centennial patterns of fire have been linked with shifts in biota across the landscape, both likely reflecting climate as the region-wide driver of change (Swetnam and Betancourt 1998; Swetnam and Anderson 2008). These shifts in biota lead to large scale patterns of homogenous stands of the same forest species with similar age composition and stand structure. Episodic dry and wet periods, insect outbreaks, wildfire or the combination of one or more of these disturbances can initiate this pattern (Swetnam and Betancourt 1998; Miao and others 2009). These then become further vulnerable to rapid shifts in climate, such as those occurring at present (Breshears and others 2005), which appear to be synchronizing forests and woodlands through massive drought-insect-related diebacks or through large wildfires. These large scale disturbance events, such as in the western U.S., might be viewed as windows of opportunity to proactively manage the landscape for diversity, using early successional stages that follow widespread mortality and prescribed fire to maintain a diversity of structures across the landscapes.

Restoration treatments are often prescribed for species or ecosystems that have been significantly or cumulatively disturbed. Because historical ranges of variation, traditionally used as references for restoration, are often 
Table 4 Managing for ecosystem change emphasizes anticipatory options for building management strategies in the face of climate change; these management strategies focus on enabling ecosystems to respond to climate change

\begin{tabular}{ll}
\hline Type & Objective \\
\hline $\begin{array}{c}\text { Enable the } \\
\text { response }\end{array}$ & $\begin{array}{c}\text { Assist transitions, population } \\
\text { adjustments, and other natural } \\
\text { adaptations }\end{array}$
\end{tabular}

Increase redundancy and buffers

Expand genetic diversity guidelines

Manage for asynchrony

Establish "neo-native" plantations and restoration sites

Promote connected landscapes

Re-align
Examples of management practices

Move species to identified habitats under climate change,

Plan for higher-elevation insect outbreaks, species mortality events, altered fire regimes,

Consider loss of species' population on warm range margins and do not attempt restoration there

Modify rotation lengths, harvest schedules, alter thinning and other silvicultural treatments

Consider replanting with different species, shift desired species to new plantation or forest locations or take precautions to mitigate likely increases in stress on plantation and forest trees

Facilitate natural selection and evolution by managing the natural regeneration process to enhance disturbances that initiate increased seedling development and genetic mixing,

Shorten generation times by increasing the frequency of regeneration and increase the effectiveness of natural selection by managing for high level of intraspecifc competition,

Diversify risk by spreading habitats or plantations over a range of environments rather than strictly within the historic distribution,

Planting with mixed species and age classes, increasing locations, sizes and range of habitats for landscape-scale vegetation treatments

Increase the number of rare plant populations targeted for restoration

Diversification of risk could also be achieved by setting aside a range of sites on NFs after disturbance events to allow the natural regeneration and successional processes identify the most resistant species and populations

With sufficient information, move germplasm in the anticipated adaptive direction; if an uncertain future is anticipated, expand seed zones sizes in all directions

Relax seed transfer guidelines to accommodate multiple habitat moves

Introduce long distance germplasm into seed mixes

Reduce homogeneity of stand structure and synchrony of disturbance patterns across broad landscapes by promoting diverse age classes, species mixes, stand diversities, genetic diversity

Reset ecological trajectories to take advantage of early successional stages that are adaptive to present rather than past climates

Consider areas that supported species in the past under similar climatic conditions to those projected for the future as new plantations or ecological restoration sites

Manage for landscapes that contain continuous habitat with few physical or biotic restrictions and through which species can move readily (recruit, establish, forage)

Evaluate and reduce fragmentation

Plan cumulative landscape treatments to encourage defined corridors as well as widespread habitat availability

For ecosystems with significantly disrupted conditions, bring ecosystem processes of the disturbed landscape into the range of current or anticipated future environments, rather than historical pre-disturbance conditions inappropriate in the face of changing climates, re-alignment with current processes and dynamics (Table 4) may facilitate recovery and adaptation to a changing climate more so than restoration to historic pre-disturbance conditions (Millar and Brubaker 2006; Willis and Birks 2006; Millar and others 2007). Here management seeks to bring processes of the disturbed landscape into the range of current or anticipated future environments (Halpin 1997) as in the case of lake levels in the Mono Lake ecosystem of California (Millar and Woolfenden 1999).

\section{Opportunities and Challenges for Managing Multiple Resources under a Changing Climate}

Opportunities exist to manage for multiple resources under a changing climate. Strategic approaches can build on initial steps to reset ecosystems after climate-driven extreme events or to proactively plan for climate change. Management practices can attempt to forestall climate change by building resistance and resilience into current ecosystems and at the appropriate time, begin to manage 
ecosystems to adapt to climate change. These opportunities will require agency consideration of its adaptive capacity.

To address climate change, agency staff will require a more technical understanding of climate change. Line officers and resource staff are faced with-and will continue to be faced with-the challenge of making decisions in an uncertain environment. Agency facilitation of a learning environment, where novel approaches to addressing climate change effects and ecosystem adaptation are supported by the agency (Baron and others 2008), will support FS employees as they attempt to achieve management goals in the face of climate uncertainty and change. Flexibility to address the inherent uncertainty about local effects of climate change in the future could be achieved through enhancing the resiliency of forests now (WRI 2008). Although evaluating priorities has always been important in resource management, the magnitude and scope of anticipated needs, combined with diminishing availability of human resources, dictate that priorities might need to be evaluated swiftly, strictly, and definitively. Consideration of methods to establish these priorities before the crisis appears would facilitate decision-making.

The adaptive capacity of the social and economic environments in which the NFs exist as well as the barriers to adaptation-physical, institutional, social, political, economic and technological — will need to be addressed. There is an urgent need for policy makers, managers, scientists, stakeholders, and the general public to share the specific evidence of global climate change and its projected consequences on ecosystems, as well as their understanding of the choices, future opportunities, risks, and difficult trade-offs. Adaptation will best be approached jointly by neighboring land managers and private land owners, or regionally, including decision-makers and stakeholders from all relevant scales of governance to guide the management of populations, species, and ecosystems that will expand and retreat across the larger landscape under climate change. This approach will require keen awareness of the fact that human communities and a range of business sectors use, and benefit from, these ecosystems and species, and they themselves have shifting needs. The approach thus calls for improved collaboration within the complex matrix of ownerships surrounding most NFs and with all interested stakeholders.

The need for ecological and social information on potential effects of climate change is great. Scientists need to develop the scientific basis for decision making under climate change and managers will be the ones who continue to develop adaptation options (Littell and others in review). Fortunately, the opportunities are great to engage in adaptive management in its broadest sense. For example, a range of sites representing the diversity of conditions on a $\mathrm{NF}$ could be set aside after disturbance events to allow natural regeneration and successional processes to identify the most resistant species and populations. Disturbed landscapes could be used as experiments in an adaptive management context that provide data for evaluating and improving management approaches and practices to adapt ecosystems to a changing climate. Implementing the expansion of the genetic guidelines for reforestation is experimental by design, and with careful documentation of such treatments, seed sources, and outplanting locations in a corporate data structure, will allow the agency to learn from both failures and successes of such plant seed mixes. As many experiences with adaptive management in a natural resource management context show, the lynchpin is ongoing monitoring of relevant indicative ecological, climatic and social variables. As climate change accelerates, and resources for managing NFs and other aspects of the changing environment become increasingly scarce, undermining the collection and accessibility of data would place the success of adaptive management fundamentally at risk.

Adaptation to climate change is increasingly viewed as a necessary and complimentary strategy to mitigationreducing greenhouse gas emissions from energy use and land use changes in order to minimize the pace and extent of climate change (Klein and others 2007). Mitigation options can have deleterious ecological consequences (for example, land cover and land use, water resources, biodiversity) on local to regional scales (Klein and others 2007). Adaptation options may have associated carbon effects (for example, energy supply, energy use). Management practices that lower vulnerabilities to uncharacteristically severe wildfire and other climate-induced mortality could meet multiple goals of mitigation and adaptation if such practices also reflected goals for other ecosystem services. Both strategies-adaptation and mitigation-are needed to minimize the potential negative effects and to take advantage of any possible positive effects from climate variability and change (Smit and others 2001; Vogel and others 2007). It will be important to assess potential tradeoffs between the two approaches and to seek strategies that achieve synergistic benefits.

Acknowledgments We thank the US Climate Change Science Program and the Lead Authors of Science and Assessment Product 4.4, Susan Julius and Jordan West and the three anonymous reviewers. Support was provided by the US Forest Service, and for Blate, from the AAAS Science \& Technology Policy Fellow Program, and the U.S. EPA.

\section{References}

Adger WN (2003) Social aspects of adaptive capacity. In: Smith JB, Klein RJT, Huq S (eds) Climate change, adaptive capacity and development. Imperial College Press, London, pp 29-49

Adger WN, Agrawala S, Mirza MMQ, Conde C, O'Brien K, Pulhin J, Pulwarty R, Smit B, Takahashi K (2007) Assessment of adaptation practices, options, constraints and capacity. In: Parry 
ML, Canziani OF, Palutikof JP, van der Linden PJ, Hanson CE (eds) Climate change 2007: impacts, adaptation and vulnerability. Contribution of Working Group II to the Fourth Assessment Report of the Intergovernmental Panel on Climate Change. Cambridge University Press, Cambridge, pp 717-743

Anderson JL, Hilborn RW, Lackey RT, Ludwig D (2003) Watershed restoration-adaptive decision making in the face of uncertainty. Chapter 9. In: Wissmar RC, Bisson PA (eds) Strategies for restoring river ecosystems: sources of variability and uncertainty in natural and managed systems. American Fisheries Society, Bethesda, MD, USA, pp 203-232

Bachelet D, Lenihan J, Drapek R, Neilson R (2008) VEMAP vs VINCERA: a DGVM sensitivity to differences in climate scenarios. Global and Planetary Change 64:38-48

Baron JS, Allen CD, Gunderson L, McKenzie D, Meyerson L, Oropeza J, Stephenson N (2008) National parks. In: Julius SH, West JM (eds) Preliminary review of adaptation options for climate-sensitive ecosystems and resources. A Report by the U.S. Climate Change Science Program and the Subcommittee on Global Change Research. U.S. Environmental Protection Agency, Washington, DC, USA

Blaikie P, Cannon T, Davis I, Wisner B (1994) At risk: Natural hazards, people's vulnerability and disasters. Routledge, London

Breshears DD, Cobb NS, Rich PM, Price KP, Allen CD, Balice RG, Romme WH, Kastens JH, Floyd ML, Belnap J (2005) Regional vegetation die-off in response to global-change-type drought. Proceedings of the National Academy of Sciences of the United States of America 102(42):15144-15148

Carroll AL, Taylor SW, Régnière J, Safranyik L (2004) Effects of climate change on range expansion by the mountain pine beetle in British Columbia. In: Shore TL, Brooks JE, Stone JE (eds), Mountain Pine Beetle Symposium: challenges and solutions, 3031 October 2003, Information Report BC-X-399. Natural Resources Canada, Canadian Forest Service, Pacific Forestry Centre, Victoria, British Columbia, CA, pp. 223-232, 298

Cash D, Borck J (2006) Countering the 'loading dock' approach to linking science and decision making: a comparative analysis of ENSO forecasting systems. Science, Technology, and Human Values 31(4):465-494

CCSP (2008) The effects of climate change on agriculture, land resources, water resources, and biodiversity. A Report by the U.S. Climate Change Science Program and the Subcommittee on Global Change Research. [Backlund P, Janetos A, Schimel D, Hatfield J, Boote K, Fay P, Hahn L, Izaurralde C, Kimball BA, Mader T, Morgan J, Ort D, Polley W, Thomson A, Wolfe D, Ryan MG, Archer SR, Birdsey RA, Dahm CN, Heath LS, Hicke JA, Hollinger DY, Huxman TE, Okin GS, Oren R, Randerson JT, Schlesinger WH, Lettenmaier D, Major D, Poff L, Running S, Hansen L, Inouye D, Kelly BP, Meyerson L, Peterson B, Shaw R] US Environmental Protection Agency, Washington, DC, USA, $362 \mathrm{pp}$

CCSP (2009) Thresholds of Climate Change in Ecosystems. A report by the U.S. Climate Change Science Program and the Subcommittee on Global Change Research. [Fagre DB, Charles CW, Allen CD, Birkeland C, Chapin FS III, Groffman PM, Guntenspergen GR, Knapp AK, McGuire AD, Mulholland PJ, Peters DPC, Roby DD, and Sugihara G] U.S. Geological Survey, Department of the Interior, Washington DC, USA, $157 \mathrm{pp}$

Dale VH, Joyce LA, McNulty SG, Neilson RP, Ayres MP, Flannigan MD, Hanson PJ, Irland LC, Lugo AE, Peterson CJ (2001) Climate change and forest disturbances. BioScience 51:723-734

Davis MB, Shaw RG (2001) Range shifts and adaptive responses to quaternary climate change: paleoclimate. Science 292(5517): 673-679

Felzer B, Kicklighter D, Melillo J, Wang C, Zhuang Q, Prinn R (2004) Effects of ozone on net primary production and carbon sequestration in the conterminous United States using a biogeochemistry model. Tellus Series B-Chemical and Physical Meteorology 56(3):230-248

GAO (2007) Climate change: agencies should develop guidance for addressing the effects on federal land and water resources.GAO07-863. Government Printing Office, Washington, DC, USA 179 $\mathrm{pp}$

Halpin PN (1997) Global climate change and natural-area protection: management responses and research directions. Ecological Applications 7(3):828-843

Harris JA, Hobbs RJ, Higgs E, Aronson J (2006) Ecological restoration and global climate change. Restoration Ecology 14(2):170-176

Hobbs RJ, Arico S, Aronson J, Baron JS, Bridgewater P, Cramer VA, Epstein PR, Ewel JJ, Klink CA, Lugo AE, Norton D, Ojima D, Richardson DM, Sanderson EW, Valladares F, Vilà M, Zamora R, Zobel M (2006) Novel ecosystems: theoretical and management aspects of the new ecological world order. Global Ecology and Biogeography 15:1-7

Intergovernmental Panel on Climate Change (2007a) Summary for policymakers. In: Solomon S, Qin D, Manning M, Chen Z, Marquis M, Averyt KB, Tignor M, Miller HL (eds) Climate change 2007: physical science basis. Contribution of Working Group 1 to the Fourth Assessment Report of the Intergovernmental Panel on Climate Change. Cambridge University Press, Cambridge, $996 \mathrm{pp}$

IPCC (2007b) Summary for policymakers. In: Parry ML, Canziani OF, Palutikof JP, van der Linden PJ, Hanson CE (eds) Climate change 2007: impacts, adaptation and vulnerability. Contribution of Working Group II to the Fourth Assessment Report of the Intergovernmental Panel on Climate Change. Cambridge University Press, Cambridge, pp 7-22

Irland LC, Adams D, Alig R, Betz CJ, Chen CC, Hutchins M, McCarl BA, Skog K, Sohngen BL (2001) Assessing socioeconomic impacts of climate change on US forests, wood-product markets, and forest recreation. BioScience 51(9):753-764

Iverson LR, Prasad AM (2001) Potential changes in tree species richness and forest community types following climate change. Ecosystems 4(3):186-199

Johnston M, Williamson T (2007) A framework for assessing climate change vulnerability of the Canadian forest sector. Forestry Chronicle 83(3):358-361

Joyce LA, Birdsey R (2000) The impact of climate change on America's forests. RMRS-GTR-59. USDA Forest Service, Rocky Mountain Research Station, Fort Collins, CO, USA 134 pp

Joyce LA (2007) The impacts of climate change on forestry. In: Adams DM, Haynes RW (eds) Resource and market projections for forest policy development: twenty five years of experience with the US RPA timber assessment, vol 14. Springer, Netherlands, pp 449-488

Klein RJT, Huq S, Denton F, Downing TE, Richels RG, Robinson JB, Toth FL (2007) Inter-relationships between adaptation and mitigation. In: Parry ML, Canziani OF, Palutikof JP, van der Linden PJ, Hanson CE (eds) Climate change 2007: impacts, adaptation and vulnerability. Contribution of Working Group II to the Fourth Assessment Report of the Intergovernmental Panel on Climate Change. Cambridge University Press, Cambridge, pp 745-777

Ledig FT, Kitzmiller JH (1992) Genetic strategies for reforestation in the face of global climate change. Forest Ecology and Management 50(1):153-169

Lemmen DS, Warren FJ (eds) (2004) Climate change impacts and adaptation: a Canadian perspective. Government of Canada, Ottawa, Ontario, CA 174 pp

Lemmen DS, Warren FJ, Lacroix J (2008) Synthesis. In: Lemmen DS, Warren FJ, Lacroix J, Bush E (eds) From impacts to adaptation: 
Canada in a changing climate 2007. Government of Canada, Ottawa, ON, pp 1-20

Lenihan JM, Bachelet D, Neilson RP, Drapek RJ (2008) Simulated response of conterminous United States ecosystems to climate change at different levels of fire suppression, $\mathrm{CO}_{2}$ emission rate, and growth response to $\mathrm{CO}_{2}$. Global and Planetary Change 64:16-25

Littell JS, Peterson DL, Millar CI, O'Halloran KA (in review) U.S. National Forests adapt to climate change through sciencemanagement partnerships. Climatic Change (in review)

McKenzie DH, Gedalof Z, Peterson DL, Mote P (2004) Climatic change, wildfire, and conservation. Conservation Biology 18(4):890-902

McLachlan JS, Hellmann JJ, Schwartz MW (2007) A framework for debate of assisted migration in an era of climate change. Conservation Biology 21(2):297-302

Millar CI, Woolfenden WB (1999) The role of climate change in interpreting historical variability. Ecological Applications 9(4):1207-1216

Millar CI, Brubaker LB (2006) Climate change and paleoecology: New contexts for restoration ecology. In: Palmer M, Falk D, Zedler J (eds) Foundations of restoration ecology: the science and practice of ecological restoration. Island Press, Washington, DC, USA, pp 315-340

Millar CI, Stephenson NL, Stephens SL (2007) Climate change and forests of the future: managing in the face of uncertainty. Ecological Applications 17(8):2145-2151

Miao S, Zou CB, Breshears DD (2009) Vegetation responses to extreme hydrological events: sequence matters. The American Naturalist. 173:113-118

Moser SC (2005) Impact assessments and policy responses to sealevel rise in three US states: an exploration of human-dimension uncertainties. Global Environmental Change, Part A: Human and Policy Dimensions 15(4):353-369

Ryan MG, Archer SR, Birdsey RA, Dahm CN, Heath LS, Hicke JA, Hollinger DY, Huxman TE, Okin GS, Oren R, Randerson JT, Schlesinger WH (2008) Land resources. In: Backlund P, Janetos A, Schimel D, Hatfield J, Boote K, Fay P, Hahn L, Izaurralde C, Kimball BA, Mader T, Morgan J, Ort D, Polley W, Thomson A, Wolfe D, Ryan MG, Archer SR, Birdsey RA, Dahm CN, Heath LS, Hicke JA, Hollinger DY, Huxman TE, Okin GS, Oren R, Randerson JT, Schlesinger WH, Lettenmaier D, Major D, Poff L, Running S, Hansen L, Inouye D, Kelly BP, Meyerson L, Peterson B, Shaw R (eds) The effects of climate change on agriculture, land resources, water resources, and biodiversity. A Report by the U.S. Climate Change Science Program and the Subcommittee on Global Change Research, Washington, DC, USA, pp 75-120

Schneider SH, Root TL (2002) Wildlife responses to climate change: North American case studies. Island Press, Washington, DC, 437 $\mathrm{pp}$

Scholze M, Knorr W, Arnell NW, Prentice IC (2006) A climatechange risk analysis for world ecosystems. Proceedings of the National Academy of Sciences of the United States of America 103(35):13116-13120

Seager R, Ting M, Held I, Kushnir Y, Lu J, Vecchi G, Huang HP, Harnik N, Leetmaa A, Lau NL, Velez J, Naik N (2007) Model projections of an imminent transition to a more arid climate in southwestern North America. Science 316:1181-1184

Smit B, Pilifosova O, Burton I, Challenger B, Huq S, Klein RJT, Yohe G, Adger N, Downing T, Harvey E (2001) Adaptation to climate change in the context of sustainable development and equity. In: McCarthy JJ, Canziani OF, Leary NA, Dokken DJ, White KS (eds) Impacts, adaptation, and vulnerability. Contribution of Working Group II to the Third Assessment Report of the Intergovernmental Panel on Climate Change. Cambridge University Press, Cambridge, pp 877-912

Smit B, Wandel J (2006) Adaptation, adaptive capacity and vulnerability. Global Environmental Change 16:282-292

Spittlehouse DL, Stewart RB (2003) Adaptation to climate change in forest management. BC Journal of Ecosystems and Management 4(1):7-17

Suffling R, Scott D (2002) Assessment of climate change effects on Canada's National Park system. Environmental Monitoring and Assessment 74(2):117-139

Swetnam TW, Betancourt JL (1998) Mesoscale disturbance and ecological response to decadal climatic variability in the American southwest. Journal of Climate 11(12):3128-3147

Swetnam TW, Anderson RC (2008) Fire climatology in the western United States: introduction to special issue. International Journal of Wildland Fire 17:1-7

USDA Forest Service (1994) RPA Assessment of the forest and rangeland situation in the United States-1993 Update. Forest Resource Report No. 27. USDA Forest Service, Washington, DC, USA, $75 \mathrm{pp}$

USDA Forest Service (2000) 2000 RPA Assessment of forest and rangelands. FS 687. USDA Forest Service, Washington, DC, USA, $78 \mathrm{pp}$

USDA Forest Service (2004) National strategy and implementation plan for invasive species management. FS-805. USDA Forest Service, Washington, DC, USA, $17 \mathrm{pp}$

USDA Forest Service (2007) USDA forest service strategic plan FY 2007-2012. FS-880. USDA Forest Service, Washington DC, USA, $32 \mathrm{pp}$

Vogel C, Moser SC, Kasperson RE, Dabelko G (2007) Linking vulnerability, adaptation and resilience science to practice: players, pathways and partnerships. Global Environmental Change 17:349-364

West C (2005) Letter and attachments. File code 4070, Letter dated July 26, 2005, Pacific Northwest Research Station, Portland, Oregon, USA

Wilbanks TJ, Kates RW (1999) Global change in local places: how scale matters. Climatic Change 43(3):601-628

Willis KJ, Birks HJB (2006) What is natural? The need for a longterm perspective in biodiversity conservation. Science 314(5803):1261-1265

World Resources Institute (WRI) in collaboration with United Nations Development Programme, United Nations Environment Programme, and World Bank (2008) World resources 2008: roots of resilience-growing the wealth of the poor. World Resources Institute, Washington, DC, USA, $277 \mathrm{pp}$

Ying CC, Yanchuk AD (2006) The development of British Columbia's tree seed transfer guidelines: purpose, concept, methodology, and implementation. Forest Ecology and Management 227:1-13 